\title{
The International Law Commission in a Mirror- Forms, Impact and Authority
}

\author{
Laurence Boisson de Chazournes
}

\section{Introduction*}

Since the early 19 th century, the codification and development of international law have been on the international diplomatic agenda. The Final Act of the Congress of Vienna of 1815 , which contains the treaties and declarations negotiated in Vienna, includes several provisions codifying practices in the fields of freedom of navigation on rivers and the precedence of diplomatic agents. ${ }^{1}$ This phenomenon continued with nearly a hundred international conferences or congresses that were held until $1914 .^{2}$ Following the First World War, attempts were made to systematize the codification and development of international law. By a resolution of 22 September 1924, the Assembly of the League of Nations established a Committee of Experts for the Progressive Codification of International Law to draw up a list of subjects "sufficiently ripe" for codification. ${ }^{3}$ Three topics were considered to meet the criterion of ripeness, and as a result, a codification conference was convened in 1930. ${ }^{4}$ Despite its meagre results, the conference was seen as an "important milestone on the road to organized and systematic codification". ${ }^{5}$

* The author wishes to thank Guillaume Guez for his very helpful assistance in the preparation of this contribution.

1 'Regulations concerning the Relative Rank of Diplomatic Agents of 19 March 1815' and 'Regulations respecting the free navigation on rivers of 29 March 1815' in Georg Friedrich de Martens, Nouveau Recueil de Traités d'Alliance, de Paix, de Trêve, de Neutralité, de commerce, de limites, d'échange etc. et de plusieurs autres actes servant à la connaissance des relations étrangères des Puissances et États d'Europe (De Dieterich 1818) 449-5o, 434-49.

2 United Nations Secretariat, 'The Progressive Development of International Law' (1947) 41 AJIL Supp. Official Documents 32, 32.

3 League of Nations, 'Resolution adopted by the League of Nations Assembly on 22 September 1924 ' (1924) League of Nations Official Journal Spec Supp 21, 10.

4 League of Nations, 'Resolution adopted by the League of Nations Assembly on 27 September 1927 ' (1927) League of Nations Official Journal Spec Supp 53, 9. The three topics were nationality, territorial waters and responsibility of States for damage done in their territory to the person or property of foreigners.

5 Jose Sette-Camara, 'The International Law Commission: Discourse on Method' in Roberto Ago (ed), International Law at the Time of its Codification: Essays in Honour of Roberto Ago (Dott. A. Guiffré 1987) 473. 
However, and quite surprisingly, the question of codification and progressive development of international law was absent from the early drafts of the Charter of the United Nations. Initially, the Dumbarton Oaks Proposals for a United Nations charter only conferred on the General Assembly the power to "initiate studies and make recommendations for the purpose of promoting international co-operation in political, economic and social fields". ${ }^{6}$ Following a Chinese proposal to extend this power "to the development and revision of the rules and principles of international law", ${ }^{7}$ States discussed at length the question of the legislative power of the General Assembly. While the idea of turning the General Assembly into a world legislature was finally rejected, there was wide agreement that the General Assembly should be charged with initiating studies and making recommendations on international law. This consensus was enshrined in the Charter of the United Nations in its Article 13, paragraph 1(a). ${ }^{8}$ However, there was much discussion about the wording of the provision. For some States, codification alone would be too narrow because it would be limited to putting existing law in writing. On the contrary, for others, adding the word revision would suggest too much change. In the end, the juxtaposition of the words "progressive development" and "codification" was retained. According to Committee II/2, these words would "establish a nice balance between stability and change". ${ }^{9}$ The mandate of the General Assembly thus reads as follows: "The General Assembly shall initiate studies and make recommendations for the purpose of $[. .$.$] encouraging the progressive development of international law and$ its codification". ${ }^{10}$

To give effect to Article 13, the General Assembly established the Committee on the Progressive Development of International Law and its Codification

6 'Dumbarton Oaks Proposals' Washington Conversations on International Peace and Security Organization (Washington DC 21 August -7 October 1944) Chapter V (B) at para 6.

7 United Nations Conference on International Organization (UNCIO) (San Francisco 25 April - 26 June 1945) III, 1.

8 For a more detailed account of the legislative history of Article 13, see Carl-August Fleischhauer and Bruno Simma, 'Article 13' in Bruno Simma et al (eds), The Charter of the United Nations: A Commentary (3rd edn, ou P 2002) 528-52; Anne-Thida Norodom, 'Article 13, paragraphe 1 (a)' in Jean-Pierre Cot, Mathias Forteau, Alain Pellet (eds), La Charte des Nations Unies: Commentaire article par article (3rd edn, Economica, 2005) 701-703.

$9 \quad \mathrm{UNCIO}\left(\mathrm{n}_{7}\right.$ ) IX, 179; see also Herbert W Briggs, The International Law Commission (Cornell University Press, 1965) 12.

10 Charter of the United Nations, adopted 24 October 1945, 1 UNTS XVI, Article 13 para$\operatorname{graph}(\mathbf{1})(\mathrm{a})$. 
(also known as the "Committee of Seventeen"). The latter recommended the establishment of the International Law Commission and prepared a first draft of its statute. By resolution 174 (II) of 21 November 1947, the General Assembly recognized the need for assistance from an international body and approved the statute of the International Law Commission. However, the establishment of the International Law Commission did not exhaust the General Assembly's function in the progressive development and codification of international law. Faced with the emergence of new areas of international law and the need for regulation, it has established other bodies over time. Examples include the United Nations Commission on International Trade Law, the Legal Sub-Committee of the Outer Space Committee or the various ad hoc committees established by the Sixth Committee such as the Ad Hoc Committee on International Terrorism or the Special Committee on the Charter of the United Nations and on the Strengthening of the Role of the Organization. In this context of multiple "law-making" bodies, the International Law Commission has retained its pre-eminent status.

In its 70 years of existence, the Commission has accomplished sterling work in many respects. Much of its output is considered to be the cornerstone of the contemporary international legal order. It is only necessary to refer to the 1969 Vienna Convention on the Law of Treaties ${ }^{11}$ or the articles on responsibility of States for internationally wrongful acts. ${ }^{12}$ However, this positive note should not distract attention from the challenges facing the Commission. Among these, the end of the "golden era" of codification, ${ }^{13}$ and the phenomenon of treaty fatigue call into question the relatively comfortable position of the International Law Commission. Questions arise: Is the progressive reduction in the number of conventions adopted as a result of the Commission's work a sign of its decline? Is the increasing diversity of instruments used by the Commission a problem in terms of impact?

To answer these questions, this contribution will first deal with the diversity of forms of the final products and the questions this diversity raises in terms of legal effects (II.). Once this framework for analyzing the Commission's work has been established, its various impacts will be examined (III.). The present contribution will then focus on the users of the Commission's work (IV.), and will also shed light on its authority (v.).

11 Adopted 23 May 1969, entered into force 27 January 1980, 1155 UNTS 331.

12 UNGA Res 56/83 (12 December 2001), annex.

13 Patricia Galvao Teles, "The work of the International Law Commission in the Present Quinquennium (2012-2016) and Possible Future Topics: How to Remain Relevant in the $21^{\text {st }}$ Century' (2014) ABDI 215, 215. 
Despite the Commission's early practice marked by a plurality of outputs, it has long been believed that its work should lead to conventions. Yet, the statute never envisaged that this would be the only outcome (A). The diversity of final products raises the question of assessing their impact. Should we consider that in the many cases where the Commission's work has not resulted in the adoption of a convention, they have little or no impact? The answer to this question involves addressing the issue of the legal effects of non-binding instruments (B).

\section{A A Diversity of Forms}

When drafting the statute of the International Law Commission, the Committee of Seventeen decided to create separate procedures for 'progressive development' and 'codification' as the tasks "vary in their nature". ${ }^{14}$ This distinction was supposed to have some impact on the form of the final product, since in the case of progressive development, only a convention was expected. ${ }^{15}$ However, this distinction proved to be unsustainable in practice and "hardly defensible scientifically", ${ }^{16}$ which led the International Law Commission to abandon it altogether. Thus, as early as 1953, the Commission stressed in its report on the draft convention on arbitral procedure that the latter contained both elements of codification and progressive development. ${ }^{17}$ In the end, this dual working approach was replaced by a "functional hybrid between codification and progressive development but proceeding under the rubric of codification alone". 18 This results in final products adopted by the Commission under the codification procedure, including both elements of codification and progressive development of international law.

14 UNGA Sixth Committee (2nd session) GAOR, Annex 1, 175.

15 Ibid; Statute of the ILC, UNGA Res 174 (II) (21 November 1947) as amended by UNGA Res 485(v) (12 December 1950) article 15 (ILC statute); see Santiago Villalpando, 'Codification Light: A New Trend in the Codification of International Law at the United Nations' (2013) 8 ABDI 117,125 .

16 James Crawford, 'The progressive development of international law: history, theory and practice' in Denis Alland et al (eds), Unity and Diversity of International Law: Essays in Honour of Professor Pierre-Marie Dupuy (Martinus Nijhoff 2014) 19 (quoting the then Secretary of the Commission, Yuen-li Liang); Alain Pellet, 'Between Codification and Progressive Development of the law' (2004) 6 International Law FORUM du droit international 15,15 .

17 ILC, 'Report of the International Law Commission on the work of its fifth session' [1953] II ILC Ybk 200, 201-202 at para 15.

18 Crawford (n 16) 19. 
Under the codification procedure, the work of the Commission need not necessarily be concluded by conventions. Article 23(1) of the Commission's statute provides for other possibilities such as the publication of a report or the adoption of a resolution by the General Assembly. ${ }^{19}$ Over time, the Commission has diversified the forms of its work products. It has adopted "draft conventions" (such as the draft convention on the elimination of future statelessness), ${ }^{20}$ "draft articles" (such as the draft articles on responsibility of States for internationally wrongful acts), ${ }^{21}$ "draft principles" (such as the draft principles on the allocation of loss in the case of transboundary harm arising out of hazardous activities), 22 "draft guidelines" (such as the guide to practice on reservations to treaties), ${ }^{23}$ "reports" (such as the final report of the Study Group on the Most-Favoured-Nation Clause), ${ }^{24}$ "model rules" (such as the model rules on arbitral procedure), ${ }^{25}$ "draft declarations" (such as the draft declaration on rights and duties of states), ${ }^{26}$ "resolutions" (such as the resolution on confined transboundary groundwater $)^{27}$ or "conclusions of the work of the Study Group" (such as the conclusions of the Study Group on the Fragmentation of International Law: Difficulties arising from the diversification and expansion of international law). ${ }^{28}$

The choice of form is a good indicator of the Commission's intention regarding the future of a final product. A report or guide is not intended to become a conventional instrument. Another indicator is the type of referral to the General Assembly. In accordance with article 23 of its statute, the Commission may recommend the convening of an international conference to conclude a convention, or simply that the General Assembly take note of the final product. ${ }^{29}$

$19 \quad$ ILC statute, article 23 paragraph 1.

$20 \quad$ ILC, 'Report of the International Law Commission on the work of its sixth session' [1954] II ILC Ybk 140, 143-47.

21 ILC, 'Report of the International Law Commission on the work of its fifty-third session' [2001] II(2) ILC Ybk 1.

22 ILC, [2006] II(2) ILC Ybk 59.

23 ILC, [2011] II(3) ILC Ybk 23.

24 ILC, (2015) UN Doc A/70/10.

25 ILC, [1958] II ILC Ybk 83.

26 ILC, [1949] I ILC Ybk 287.

27 ILC, [1994] II(2) ILC Ybk 135.

28 ILC, [2006] II(2) ILC Ybk 177 at para 251.

29 See for instance, the draft articles on the law of treaties where the International Law Commission recommended the convening of an international conference of plenipotentiaries be convened: ILC, [1966] II ILC Ybk 177 at para 36; see also the draft articles on responsibility of States for internationally wrongful acts where it recommended that the General Assembly take note of the report: ILC, [2001] II(2) ILC Ybk 25 at para 72. 
Not all final products of this "wide palette of results" 30 are thus destined to become conventional instruments. ${ }^{31}$ Their impacts may vary. Therefore, the focus should not be limited to products that have given rise to conventions; that would ignore much of the Commission's work.

\section{B Hard and Soft, Soft and Hard: the Law in All Its Forms}

The Commission's impact has long been assessed in the light of the conventions resulting from its work. ${ }^{32}$ In the absence of conventions in force, it is argued that the Commission's final products have little or no impact since they are not binding. Behind this prism lies the division between hard law and soft law, or binding law and non-binding law.

To conceive the distinction between binding law and non-binding law in the "Big Bang way"33 - i.e. that what is not binding has no legal effect ${ }^{34}-$ is highly simplistic. Rules can have limited normative value, "either because the instruments containing them are not legally binding, or because the provisions in question, although contained in a binding instrument, do not create an obligation under positive law, or create only loosely binding obligations."35 Although they have a limited normative value, these rules, which form what is called soft law, are not without effect. They can expand the "Law's Empire" 36 by clearing unexplored normative fields. In doing so, it may incentivize States to put these newly explored issues on the international negotiating agenda. Soft law instruments can also be a first step towards the conclusion of legally binding instruments. As such, they can serve as a basis for work. They can also aim at clarifying the law and proposing new developments. All these roles see soft

$30 \quad$ Villalpando (n 15) 125 .

31 Yves Daudet, 'Sujets futurs et problèmes du processus législatif international' in International Law Commission Fifty Years After: An Evaluation (United Nations 200o) 11920 ; Vaughan Lowe, 'Future Topics and Problems of the International Legislative Process' in International Law Commission Fifty Years After: An Evaluation (United Nations 2000) 128.

32 See, for instance, Christian Tomuschat, "The International Law Commission - An outdated institution?' (2006) 49 GYIL 77, 84.

33 Georges Abi-Saab, 'Cours général de droit international public' (1987) 207 RdC 204; Laurence Boisson de Chazournes and Sandrine Maljean-Dubois, 'Normes parajuridiques, système concurrent ou complémentaire: le rôle des ONG internationales et de la soft law' in Brigitte Feuillet-Le Mintier (ed), Normativité et biomédecine (Economica 2003) 217 .

34 Prosper Weil, 'Vers une normativité relative en droit international?' (1982) 86 RGDIP 5.

35 'soft law' in Jean Salmon (ed), Dictionnaire de droit international public (Bruylant 2001).

36 Georges Abi-Saab, 'Éloge du "droit assourdi” Quelques réflexions sur le rôle de la soft law en droit international contemporain' in Nouveaux itinéraires en droit: Hommage à François Rigaux (Bruylant 1993) 64. 
law as transitional law. But there are other cases where soft law instruments can be final products and not just intermediate steps. The best-known case is where a soft law instrument aspires to serve as a model for other instruments. In these cases, it has all the characteristics of a hard law instrument, except that it is not binding. A striking example is the United Nations Commission on International Trade Law Model Law on International Commercial Arbitration. ${ }^{37}$ Very often, States integrate the Model Law into their national systems without change. In the case of technical regulations, soft law instruments are often resorted to due to their evolving nature and high degree of technicality. These soft law instruments act as law in a specific sector. ${ }^{38}$ This is the case, for instance, of norms of the International Organization for Standardization (ISO) in the field of global industrial production and distribution or the Codex Alimentarius on food, food production, and food safety.

As we have just seen, soft law instruments blur the limits of the threshold of what constitutes law since the absence of a binding character does not exclude the existence of legal effects. ${ }^{39}$ There is therefore a normative gradation. The final products of the International Law Commission fit into this context and run on the entire scale of normativity. ${ }^{40}$

The impact of the Commission, i.e. the consequences of its work, is multifaceted. In some instances, the Commission's final products constitute reference materials that serve as sources of inspiration or models (B.). In others, they provide practical tools to resolve or clarify legal issues (C.). The Commission also plays an important role in making State practice available (D.). However, the most well-known impact is undoubtedly its contribution to the codification and progressive development of international law. Over the decades, the Commission's work has transposed many rules of customary international law into easily accessible pronouncements, thus providing legal certainty

37 UNCITRAL Model Law on International Commercial Arbitration, UN Doc A/40/17, 24 ILM 1302 (1985), with amendments adopted on 7 July 2006.

38 Laurence Boisson de Chazournes, 'Standards et normes techniques dans l'ordre juridique contemporain: quelques réflexions' in Laurence Boisson de Chazournes and Marcelo Kohen (eds), International Law and the Quest for Its Implementation - Le droit international et la quête de sa mise en œuvre: Liber Amicorum Vera Gowlland-Debbas (Brill 2010) 351-76.

39 Boisson de Chazournes and Maljean-Dubois (n 33) 217.

40 Ibid. 
and predictability. It has also resulted in the establishment of numerous new rules (A.).

\section{A The Commission's Contribution to the Codification and Progressive Development of International Law}

According to article 1 of its statute, "[t]he International Law Commission shall have for its object the promotion of the progressive development of international law and its codification". The implementation of this object has yielded different results. In some cases, it has taken a formal turn with the conclusion of treaties (1.). In others, however, it has remained in the form of soft law instruments. This has a number of implications, particularly for the elements of progressive development (2.).

\section{Formal Codification and Progressive Development of} International Law

A number of treaties have resulted from the International Law Commission's work. A quantitative overview sheds light on this impact. Of the 41 topics dealt with by the Commission, three of which were the subject of a dual examination, ${ }^{41} 23$ conventions were adopted. For some, this may not seem like much. For others, this may be satisfactory. If the analysis is taken a little further, however, the picture is more nuanced. Indeed, of the 23 conventions produced, 19 have entered into force. Of these, 7 have been ratified by less than forty parties. ${ }^{42}$ Ultimately, only 12 conventions have been widely ratified. These figures are indicative of the relative impact these treaties may have in terms of coverage and binding character.

However, the analysis cannot be limited to a sole quantitative approach. Despite their relatively small number, these conventions are of material importance. Many of them can be considered amongst the most important treaties ever concluded. ${ }^{43}$ They are the cornerstone of the international legal order. Examples include the 1969 Vienna Convention on the Law of Treaties, the $1961 \mathrm{Vi}$ enna Convention on Diplomatic Relations ${ }^{44}$ and the 1963 Vienna Convention on Consular Relations. ${ }^{45}$ In addition, these conventions cover a wide range of

41 These three topics are the question of international criminal jurisdiction (1949-50 and 1994), the draft code of offences against the peace and security of mankind (1954 and 1996) and on the most-favoured-nation clause (1978 and 2015).

42 Anne-Thida Norodom, 'CDI' in Hervé Ascensio et al (eds), Dictionnaire des idées reçues en droit international (Pedone 2017) 65-66.

43 Pellet (n 16) 21; Galvao Teles (n 13) 215.

44 Adopted 18 April 1961, entered into force 24 April 1964, 500 UNTS 95.

45 Adopted 28 August 1967, entered into force 27 September 1967, 596 UnTs 261. 
areas of international law, ranging from diplomatic and consular relations to the law of the sea, the use of international watercourses and the succession of States. They also widely codify customary international law. Therefore, limiting the analysis to a quantitative point of view would not account for the importance of these conventions in international life. Even though they are not widely ratified, they reflect norms that are opposable to a large number of States.

That said, over the past two decades, only two conventions have been concluded on the basis of the Commission's work, namely the 1997 Convention on the Law of the Non-Navigational Uses of International Watercourses ${ }^{46}$ and the 2004 Convention on Jurisdictional Immunities of States and their Property. ${ }^{47}$ Does this reveal the existence of a crisis? Not necessarily. One of the reasons given for this situation is the exhaustion of subjects suitable for codification by convention. The topics under consideration by the Commission may prove otherwise. ${ }^{48}$ Besides, as mentioned above, conventions are not the only outcome to be achieved by the Commission. Indeed, not all topics placed on the agenda of the Commission are conducive to the adoption of treaties.

In fact, this interest or disinterest in adopting treaties should be placed in a broader context. The decline in the number of treaties adopted in recent years is not unique to the International Law Commission. Treaty fatigue is becoming more prevalent, at least in some areas of international law. ${ }^{49}$ More generally, there is less of an appetite for the adoption of multilateral treaties and, when multilateral conventions are adopted, they often do not attract a large number of ratifications. A historical explanation can be given for this phenomenon. After the Second World War, treaties were used as a means to shape a new order. Similarly, in the post-colonial period, treaties were used to make international law more inclusive. During the Cold War, treaties ensured that all key stakeholders were bound by the same rules. And in the aftermath of the fall of the Berlin Wall, a number of treaties were intended to craft a so-called new legal, political and economic order. That period now seems to be over.

Today, in the alternative, other types of multilateral instruments are adopted, including G2o declarations, memoranda of understanding and Heads of State declarations, amongst others. A striking example is the Global Compact on Safe,

46 Adopted 21 May 1997, entered into force 17 August 2014, UNTS registration no 52106.

47 Adopted 2 December 2004, not yet in force; UNGA Res A/59/508 (30 November 2004).

48 See for instance, the topic on "Crimes against humanity".

49 Joost Pauwelyn, Ramses A Wessel and Jan Wouters, 'When Structures Become Shackles: Stagnation and Dynamics in International Lawmaking' (2014) 25 EJIL 733, $734-36$. 
Orderly and Regular Migration, adopted under the aegis of the United Nations on 11 July 2018, which constitutes a "non-legally binding, cooperative framework". 50 And when multilateral treaties are adopted, their form and content may vary. A good example is the Paris Agreement, the content of which is essentially procedural in nature with hardly any substantive obligations. ${ }^{51}$ It is notable that the Paris Agreement was negotiated together with a decision of the Contracting Parties to the United Nations Framework Convention on Climate Change in which substantive commitments were integrated. ${ }^{52}$ Hard and soft, soft and hard, it is hard to keep track.

In the end, the International Law Commission's final products are in line with these normative fluctuations. The Commission is not "Lost in Translation". One may wonder whether the Commission itself should not suggest to the General Assembly that other types of instruments than conventions be adopted for some of its final products.

2

\section{Informal Codification and Progressive Development of} International Law

Final products that do not result in conventions also contribute to this effort to codify and progressively develop international law. However, the soft form of these instruments has some consequences. It thus becomes important to distinguish between rules that codify international law and those that progressively develop it. Indeed, only those reflecting customary law can be directly used, even in the absence of treaties. In practice, however, the distinction is not always made. This is particularly so "when there is a legal vacuum of authority relevant to an issue". ${ }^{53}$ In such cases, whatever is available is used without paying much attention to its legal status. The articles on responsibility of States for internationally wrongful acts constitute a prime example. Many international courts and tribunals rely on them as if they were a treaty. ${ }^{54}$ They

50 'Final draft of 11 July 2018', Intergovernmental Conference to Adopt the Global Compact on Safe, Orderly and Regular Migration, Preamble, Recital 7 .

51 Adopted on 12 December 2015, entered into force 4 November 2016, UNTS registration no 54113 .

52 Laurence Boisson de Chazournes, 'Regards sur l'Accord de Paris - Un accord qui bâtit le futur' in Marta Torre-Schaub and Mireille Delmas-Marty (eds), Bilan et perspectives de l'Accord de Paris (COP 21) - Regards croisés (Paris, IRJs Editions 2017) 97-106; Pieter Jan Kuijper, 'Acceptance speech of the Maastricht Prize for International Law' (2016) (on file with the author).

53 David D. Caron, 'The ILC Articles on State Responsibility: The Paradoxical Relationship between Form and Authority' (2002) 96 AJIL 857, 866-69.

Ibid. 
make no distinction between articles codifying international law and those progressively developing it. This may prove problematic. As indeed acknowledged by the Commission in the commentaries, some articles "reflect the progressive development of international law".55

In this context, the Commission has a role to play in clarifying or recalling that its projects constitute both codification and progressive development of international law. Where possible, the Commission should specify the category in which a provision falls. This would provide valuable assistance to users of its final products and would also allay the concerns of some States that the Commission's pronouncements are given too much authority on the assumption that they reflect existing law. ${ }^{56}$ This is what it did, for example, with article 48, paragraph 2, of the articles on responsibility of State for internationally wrongful acts. In the accompanying commentary, it stated that the paragraph "involves a measure of progressive development, which is justified since it provides a means of protecting the community or collective interest at stake." 57

However, this level of detail is not always possible. As the Commission admitted, some drafts "it has formulated contain elements of both progressive development as well as of codification of the law and, as in the case of several previous drafts, it is not practicable to determine into which category each provision falls". ${ }^{58}$ Ultimately, it is important to assess what the International Law Commission's approach has been on a particular point and to bear in mind that it is not always possible to draw a fine line between existing law and progressive development.

\section{B The Commission's Final Products as Sources of Inspiration or Models} The final products of the Commission have often played an important role as sources of inspiration or models. The United Nations Convention on the NonNavigational Uses of International Watercourses is illustrative. Even before its late entry into force on 17 August 2014, this instrument had a considerable impact on State practice. A number of agreements have been concluded on

55 ILC, 'Report of the International Law Commission on the work of its fifty-third session' [2001] II (2) ILC Ybk 1, 114 at para 3, 141 at para 1.

56 See in that regard Danae Azaria in Section 4 of this volume.

57 ILC (n 55) 127 at para 12; see also 'Guide to practice on reservations to treaties', [2011] III (3) ILC Ybk 73 .

58 ILC, 'Report of the International Law Commission on the work of its twenty-sixth session' [1974] II(1) ILC Ybk 174; For a comprehensive account of the Commission's practice, see Donald M McRae, "The Interrelationship of Codification and Progressive Development in the Work of the International Law Commission' (2013) 111 JILD 75, 81-86. 
the basis of its provisions. For example, the Revised Protocol on Shared Watercourses in the Southern African Development Community of 7 August 200059 largely copied parts of the United Nations Watercourses Convention. Similarly, the Convention greatly influenced the Charter of Senegal River Waters, ${ }^{60}$ the Niger Basin Water Charter, ${ }^{61}$ the Agreement on the Nile River Basin Cooperative Framework ${ }^{62}$ and the Water Charter for Lake Chad Basin. ${ }^{63}$ Even more interesting, certain agreements have been concluded on the basis of the Commission's articles on the law of the non-navigational uses of international watercourses. Examples include the 1992 Helsinki Convention on the Protection and Use of Transboundary Watercourses and International Lakes ${ }^{64}$ and the 1995 Cooperation Agreement for the Sustainable Development of the Mekong River Basin. ${ }^{65}$ The principles and rules codified and developed by the Commission have therefore served as a reference tool for the negotiations of a set of treaty instruments. ${ }^{66}$

Likewise, the articles on the law of transboundary aquifers are another example of that impact. ${ }^{67}$ Upon completion of its work, the Commission recommended that the States concerned make appropriate bilateral or regional arrangements for the proper management of their transboundary aquifers on the basis of the principles enunciated in the articles. ${ }^{68}$ Building on these articles, Argentina, Brazil, Paraguay and Uruguay concluded the Guarani Aquifer Agreement on 2 August 2010. ${ }^{69}$

Finally, special mention should be made of the draft statute for an international criminal court and its marked influence on the Rome Statute of the

\footnotetext{
59 Adopted 7 August 200o, entered into force 22 September 2003.

6o Adopted 28 May 2002.

$61 \quad$ Adopted 30 April 2008.

62 Adopted 14 May 2010, not yet in force.

63 Adopted April 2012.

64 Adopted 17 March 1992, entered into force, 6 October 1996, 1936 UnTs 269.

65 Adopted 5 April 1995 .

66 See Laurence Boisson de Chazournes, Fresh Water in International Law ( $1^{\text {st }}$ edn, OuP 2015) 7-53.

67 ILC, 'Report of the International Law Commission on the work of its sixtieth session' [2008] II(2) ILC Ybk 1, 22-43. For a critical assessment of the inclusion of an article dealing with "Sovereignty of aquifer States" (Article 3), see Stephen C. McCaffrey, 'The International Law Commission Adopts Draft Articles on Transboundary Aquifers', (2009) $103(2)$ AJIL 272.

68 Ibid.

69 Adopted 2 August 2010, not yet in force, preamble, Recital 3; see Lilian del Castillo Laborde, 'The Rio de la Plata River Basin: The Path Towards Basin Institutions' in Laurence Boisson de Chazournes and Mara Tignino (eds), International Water Law (Edward Elgar 2015) 388-411.
} 
International Criminal Court. ${ }^{70}$ It acted as a catalyst for the establishment of the International Criminal Court. Welcoming the report of the Commission on the statute of a criminal court, the General Assembly in its resolution 49/53 decided to initiate the procedure for the establishment of the International Criminal Court. Although the Commission's draft statute was not ultimately adopted, it enabled the prompt adoption of the Rome Statute on 17 July 1998 by framing the discussions.

\section{The Commission's Final Products as Clarifying Tools}

In some cases, the Commission's final products aim at clarifying previous work. The Commission's final products are the result of compromises and negotiations, which can lead to a broad formulation of certain principles or rules. Over time, there may be a need to clarify these principles or rules so that they can be easily used in practice. Several treaty-related projects fall within this context such as the project on subsequent agreements and subsequent practice in relation to interpretation of treaties ${ }^{72}$ and that on reservations to treaties. ${ }^{73} \mathrm{In}$ particular, with regard to the latter, the Commission noted that the provisions concerning reservations in the 1969 Vienna Convention on the Law of Treaties, the 1978 Vienna Convention on Succession of States in Respect of Treaties ${ }^{74}$ and the 1986 Vienna Convention on the Law of Treaties between States and International Organizations or between International Organizations ${ }^{75}$ could be clarified and developed as they "were too general to act as a guide for State practice and left a number of important matters in the dark". ${ }^{76}$ This resulted in the adoption of a guide to practice on reservations to treaties. ${ }^{77}$

Other work has also aimed at developing legal techniques to resolve conflicts that may arise in the interpretation and application of international law. This is the case, for instance, of the report entitled "Fragmentation of international

$70 \quad$ ILC, 'Report of the International Law Commission on the work of its forty-sixth session' [1994] II (2) ILC Ybk 1, 26-75.

71 UNGA Res 49/53 (17 February 1995).

72 ILC, 'Draft conclusions on subsequent agreements and subsequent practice in relation to the interpretation of treaties' (2018) UN Doc A/73/10, 12; the International Law Commission at its seventieth session, in 2018, submitted the draft conclusions to the General Assembly (UN Doc A/73/10, para 49).

73 UNGA Res 68/111 (16 December 2013).

74 Adopted on 23 August 1978, entered into force 6 November 1996, 1946 UNTS 3.

75 Adopted 21 March 1986, not yet in force, A/CONF.129/15.

76 ILC, 'Report of the International Law Commission on the work of its forty-fifth session' [1993] II (2) ILC Ybk 427.

77 ILC, 'Report of the International Law Commission on the work of its sixty-third session' [2011] II (2) ILC Ybk 1, 26-38; see also ILC (n 54). 
law: difficulties arising from the diversification and expansion of international law". Its purpose was to "provide a toolbox with the help of which lawyers dealing with that problem (or any other comparable issue) may be able to proceed to a reasoned decision".78 Four types of "collision rules" and a "user manual" have thus been developed by the Commission to deal with regime conflicts. This report has proved useful in addressing the difficulties raised by Article 103 of the Charter of the United Nations as well as in other contexts. ${ }^{79}$

\section{The Commission's Contribution to the Availability of State Practice}

The practical usefulness of the Commission's work is not limited to the final products. As part of the codification and progressive development process, the Commission carries out an in-depth study of State practice. This results in compendia of State practices for each topic addressed. This is undoubtedly a major contribution from the Commission. ${ }^{80}$

Article 24 of the statute also entrusts the International Law Commission with the task of exploring "ways and means for making the evidence of customary international law more readily available".81 The objective at the time was to "remed[y] the present unsatisfactory state of documentation". ${ }^{2}$ Under that provision, the Commission adopted in 1950 a Report on Ways and Means for Making the Evidence of Customary International Law more readily available. ${ }^{83}$ This report has proved extremely useful both for practitioners and for the Commission itself. It led to the emergence of new legal publications ${ }^{84}$ and "provided clues as to where State practice related to international law could be found".85

78 ILC, 'Fragmentation of international law: Difficulties arising from the diversification and expansion of international law - Report of the Study Group of the International Law Commission' (2006) UN Doc A/CN.4/L.682, 17.

79 Al-Jeddav The United Kingdom, App no. 27021/o8 (ECtHR, 7 July 2011), para 57.

8o For an example of the use of these compendia, see Jurisdictional Immunities of the State (Germanyv Italy: Greece intervening) (Merits) [2012] ICJ Rep 99, 134-135 at para 77.

81 ILC statute, article 24.

82 ILC, 'Ways and means of making the evidence of customary international law more readily available: Preparatory work within the purview of article 24 of the Statute of the International Law Commission - Memorandum submitted by the Secretary-General' (1949) UN Doc A/CN.4/6, 5 .

83 ILC, 'Report of the International Law Commission on the work of its second session' [1950] II ILC Ybk 364, 367-74.

84 ILC, 'Identification of customary international law - Ways and means of making the evidence of customary international law more readily available - Memorandum submitted by the Secretary-General' (2018) UN Doc A/CN.4/710,3 at para 5 .

85 Mathias Forteau, 'Comparative International Law Within, Not Against, International Law: Lessons from the International Law Commission' in Anthea Roberts et al (eds), Comparative International Law (OUP 2018) 169. 
With the advent of the Internet and the emergence of a multitude of new States, an update was necessary. It is therefore welcome that the 1950 Report has finally been updated by the Secretariat. It is regrettable, however, that this memorandum prepared by the Secretariat has not been more widely advertised and disseminated. ${ }^{86}$

More generally, the work of the Commission has had an impact on the way international law is taught. The careful study of State practice and the Commission's pronouncements codifying and progressively developing international law have made it possible to lay down a large number of rules in writing. As a result, doctrine and case analysis have been replaced by written law. ${ }^{87}$ This unintended impact has led to a wider dissemination of this legal corpus.

In summary, the Commission's impacts are varied. Whether by serving as a source of inspiration, providing clarifying tools or resulting in treaties, the Commission's work has proved very valuable. These impacts are also indicative of the predominant place that this body still occupies today, particularly for the users of its work.

That said, this positive picture must not mask the failures that the Commission has experienced. The reasons for these failures are diverse. For some, such as the draft articles on the status of the diplomatic courier and the diplomatic bag not accompanied by diplomatic courier, ${ }^{88}$ or the 1975 Vienna Convention on the Representation of States in their Relations with International Organizations of a Universal Character, ${ }^{89}$ it was a lack of balance that led to their downfall. ${ }^{90}$ For others, such as the 1986 Vienna Convention on the Law of Treaties between States and International Organizations or between International Organizations, it was the lack of interest of the recipients that undermined them. Likewise, faced with very little interest from States in the

86 This situation could change. In referring the work on 'Identification of customary international law' to the General Assembly in accordance with article 23 of its statute, the Commission recommended to the General Assembly that it take note of the memorandum of the Secretariat and follow up on its suggestions (see ILC, 'Report of the International Law Commission on the work of its seventieth session' (2018) UN Doc A/73/ 10, at para. 63). In this regard, see UNGA Res 73/203 (20 December 2018).

87 Georges Abi-Saab, 'Uses and Perils of Codification' in International Law Commission Fifty Years After: An Evaluation (United Nations 2000) 168.

88 ILC, 'Report of the International Law Commission on the work of its forty-first session' [1989] II (2) ILC Ybk 1, 14-49.

89 Adopted 14 March 1975, not yet in force, UN Doc A/CONF.67/16.

9o Tomuschat $\left(\mathrm{n}_{32}\right) 86-87$. 
Declaration on Rights and Duties of States, the General Assembly decided to defer consideration of the draft indefinitely. ${ }^{91}$ There are also certain final products such as the 1983 Vienna Convention on Succession of States in respect of State Property, Archives and Debts ${ }^{92}$ which are the mark of a certain historical period. In yet other cases, the study of certain topics did not lead to the production of a final product. This was the case for shared natural resources (oil and gas). The Commission decided not to develop it, particularly because of its political sensitivity. ${ }^{93}$

\section{The "regard des autres" on the Commission}

As the artist Marcel Duchamp once stated, "the painting is made as much by the viewer as by the artist". 94 This idea is reflected in Marc Chagall's magnificent work entitled "The visit of the self-portrait". In this canvas, the painter faces his portrait. While the right eye of the portrait is uncovered, the head of the painter contemplating his portrait covers the left eye. This captures the idea of a dual perspective. The right eye represents the perception of the artist producing the work while the covered left eye represents the external perspective, that of the viewer.

The external perspective on the Commission is held by many actors. They include courts and tribunals, international organizations, jurisconsults, negotiators of international agreements, diplomats, counsels pleading before international courts and tribunals, non-governmental organizations and academics. Interestingly, this great diversity of "external" viewers reveals a relatively uniform perception of the Commission: that of a body with great authority.

International courts and tribunals have often referred to the Commission's work, whatever its form and status. Amongst these jurisdictions, the International Court of Justice holds a special place. As Dame Rosalyn Higgins noted during the Commission's sixtieth anniversary celebrations, "it is remarkable to note the high percentage in which reference has been made to the work of the

91 UNGa Res 596 (VI) (7 December 1951).

92 Adopted on 8 April 1983, not yet in force, UN Doc A/CONF.117/16.

93 ILC, 'Report of the International Law Commission on the work of its sixty-second session' [2010] II (2) ILC Ybk 1, 200-201 at paras 374-84.

94 Georges Charbonnier, Entretiens avec Marcel Duchamp [réalisés en 1960], André Dimanche, 1994, 81-82: "Je crois sincèrement que le tableau est autant fait par le regardeur que par l'artiste" (author's translation). 
International Law Commission". ${ }^{95}$ This still holds true today. ${ }^{96}$ In general, the Court refers to the work of the Commission in determining the customary status of particular rules. While in theory the Court should survey State practice and opinio juris on its own, "in practice, [it] has never found it necessary to undertake such an inquiry ... and instead has made use of the best and most expedient evidence available". ${ }^{97}$ The work of the Commission has fulfilled that role. Thus, for example, in the North Sea Continental Shelf case, the Court decided that, on the basis of the extensive discussions contained in the reports of the International Law Commission, article 6 of the 1958 Geneva Convention on the Continental Shelf was not customary law. ${ }^{98}$ This is only one of many examples where the Court has used the work of the Commission to establish the customary character of a rule. This use by the International Court of Justice of the work of the Commission is of great importance and it is a testament to the Court's respect and recognition for the expertise of the International Law Commission

This relationship between the International Court of Justice and the International Law Commission is not one-way. The Commission has relied heavily on the decisions and judgments issued by the International Court of Justice in its work. This has been the case, for example, in the areas of the law of treaties, the law of the sea and State responsibility. Sometimes the Commission has even paused its work pending a decision by the Court. This was the case with guarantees and promises of non-repetition when these issues were at play in the LaGrand case. ${ }^{99}$ Besides, membership in these two institutions is often linked. Many judges of the International Court of Justice are former members of the Commission. Of these, nine served as President of the Court. ${ }^{100}$ Currently, seven judges have previously served as members of the Commission. These two institutions are thus intrinsically linked, which explains their trust in each other's work.

95 Rosalyn Higgins, 'Keynote Address by H.E. Judge Rosalyn Higgins, President of the International Court of Justice, at the Sixtieth Anniversary of the International Law Commission' (Geneva, 19 May 2008) 2.

96 See the contribution by Danae Azaria in Section 4 of this volume. See also Michael Peil, 'Scholarly Writings as a Source of Law: A Survey of the Use of Doctrine by the International Court of Justice' (2012) 1(3) CJICL 136, 152.

97 Peter Tomka, 'Custom and the International Court of Justice' (2013) 12 LPICT 195, 197.

98 North Sea Continental Shelf (Merits) [1969] ICJ Rep 3, 33-51; Jurisdictional Immunities (n 8o) 127 at para 64 .

99 Higgins (n 95) 2; LaGrand (Germany v United States of America) (Merits) [2001] ICJ Rep 466.

100 In chronological order: Manfred Lachs, Eduardo Jiménez de Aréchaga, Sir Humphrey Waldock, Taslim Elias, Nagendra Singh, Mohammed Bedjaoui, Stephen Schwebel, Shi Jiuyong, and Peter Tomka. 
Other international courts and tribunals have also referred to the work of the Commission but in a less systematic manner, which is sometimes even questionable. In this regard, reference can be made to the use of the articles on the responsibility of international organizations ${ }^{101}$ by the European Court of Human Rights in the Behramiv France and Saramativ France, Germany and Norway cases. ${ }^{102}$ Interestingly, the references made by these jurisdictions to the work of the Commission are rarely accompanied by explanations. As if invoking the Commission were sufficient on its own: references to its work are perceived as an argument of authority. Examples include references made to the articles on State responsibility by numerous courts, such as the InterAmerican Court of Human Rights, ${ }^{103}$ the International Tribunal for the Law of the Sea ${ }^{104}$ and arbitral tribunals. ${ }^{105}$

However, this use of the work of the Commission is not always without its problems. Unlike the International Court of Justice, few other international jurisdictions distinguish between existing law and progressive development. ${ }^{106}$ This may lead to the application of rules that have not yet been accepted as binding by the international community. In other cases, projects were used despite the fact that their scope did not cover the legal issue at stake. In this regard, one can mention the references made by investment tribunals to the "Guiding principles applicable to unilateral declarations of States capable of

101 ILC, 'Draft articles on the responsibility of international organizations' [2011] II(2) ILC Ybk 40.

102 Behramiv France and Saramativ France, Germany and Norway App no. 71412/o1 and 78166/ ol (ECtHR, 2 May 2007), paras 28-34; see for critique, Laurence Boisson de Chazournes and Vassilis Pergantis, 'A propos de l'arrêt Behrami et Saramati: un jeu d'ombre et de lumière dans les relations entre l'ONU et les organisations régionales' in Marcelo Kohen, Robert Kolb and Djacoba Liva Tehindrazanarivelo (eds), Perspectives of International Law in the 21st Century: Liber Amicorum Christian Dominicé in Honour of its 8oth Birthday (Martinus Nijhoff 2012) 191-223.

103 Gutiérrez and Family v Argentina (Merits, Reparations and Costs Judgment) InterAmerican Court of Human Rights Series C No 271 (25 November 2013), para 78, note 163 .

$104 M / V$ 'Saiga' (No 2) (Saint Vincent and the Grenadines $v$ Guinea) (Judgment of 1 July 1999) ITLOS Reports 1999, 41 at para 82, 45 at para 98.

105 Jan de Nul NV and Dredging International NVv Egypt (Award, 2008) ICsID Case No ARB/ 04/13, [155]-[173]; ConocoPhillips Petrozuata B.V., and others $v$ Bolivarian Republic of Venezuela (Decision on Jurisdiction and Merits, 2013) ICSID Case No ARB/o7/3o, [339]. For a detailed account of the decisions of international courts, tribunals and other bodies referring to the State responsibility articles, see UNGA, 'Report of the Secretary-General', UN Doc A/62/62,UN Doc A/65/76, UN Doc A/68/72 and UN Doc A/71/8o.

106 Marija Dordeska, 'The Process of International Law-Making: The Relationship between the International Court of Justice and the International Law Commission' (2015) 15 ILCR 7,37 . 
creating legal obligations" when dealing with consent to jurisdiction through domestic legislation. ${ }^{107}$ These various examples, although sometimes problematic, are nevertheless indicative of the authority enjoyed by the Commission.

This perception of authority is not just that of international courts and tribunals. Other actors similarly perceive the Commission as authoritative. This is the case of the General Assembly and other United Nations bodies that have submitted topics to the International Law Commission. These proposals are a mark of recognition of the expertise and authority enjoyed by the Commission. This was made clear when the United Nations Environment Programme recommended in 2009 that the International Law Commission "examine the existing international law for protecting the environment during armed conflict and recommend how it can be clarified, codified and expanded" as "the leading body with expertise in international law".108 Finally, the numerous but difficult to measure - uses made by professors, diplomats, legal advisers, non-governmental organizations, and counsels also bear testament to the authority of this body.

The "regard des autres" helps to illuminate the authority of the International Law Commission. Many actors refer deferentially to the work of the Commission. Sometimes this deference goes too far and the work is relied upon almost blindly. The use of the final products must be done with care. The Commission has a role to play in facilitating the appropriation of its final products by users.

\section{Concluding Remarks: the Authority of the International Law Commission}

As we have seen, the International Law Commission enjoys an authority per $s e$. The notion of "authority" refers to a voluntary submission, ${ }^{109}$ grounded in

107 Tidewater Inc. $v$ Venezuela (Decision on Jurisdiction, 2008) ICSID Case No ARB/10/5, [92]; Mobil v Venezuela (Decision on Jurisdiction, 2010) ICSID Case No ARB/o7/27, [89]; Laurence Boisson de Chazournes, 'Rules of Interpretation and Investment Arbitration' in Meg Kinnear, Geraldine Fischer, Jara Minguez Almeida, Luisa Fernanda Torres, Mairée Uran Bidegain (eds), Building International Investment Law, The First 50 Years of ICSID (Kluwer Law International 2015) 18-23.

108 UNEP, Protecting the Environment During Armed Conflict - An Inventory and Analysis of International Law (UNEP, 2009) 53, Recommendation 3; see also ILC, 'Report of the International Law Commission on the work of its sixty-third session' [2011] II(2) ILC Ybk 1, 211-21, 219 at para 23 .

109 Max Weber, The Theory of Social and Economic Organization ( $1^{\text {st }}$ edn, The Free Press 1964) 324 . 
recognition. ${ }^{110}$ Put simply, the person or institution treated as an authority is recognized as having "the right to speak credibly". ${ }^{111}$ There is no hierarchical relationship between an authority holder and the subjects. In other words, a pronouncement is accepted as authoritative, "not because of a threat of sanction [...], or through persuasion, but because it emanates from a particular person".12 As defined, the notion of 'authority' therefore excludes coercion and persuasion. This is well illustrated by Hannah Arendt's parable of the father: "[a] father can lose his authority by beating his child or by starting to argue with him". 113

The authority of the Commission rests on multiple foundations. Its universal character, composition and working methods have played a major role in the establishment of this authority. The Commission was established by the United Nations General Assembly as a subsidiary organ with universal membership. Its statute provided for a balance to be struck between regional representativeness ${ }^{114}$ and legal expertise. ${ }^{115}$ Over the years, States have appointed academics, former or current legal advisers, diplomats and sometimes ministers, as members of the Commission. Legal expertise is important but closely linked to the need to ensure representation of the main forms of civilization and of the principal legal systems of the world. In this regard, the number of members has increased from fifteen to thirty-four in order to accompany the increase in the number of United Nations members. ${ }^{116}$ At the same time, a fixed distribution of seats was established to ensure equitable geographical distribution. Such universal composition is important in explaining the authority of the Commission. So are the working methods. They include the nomination of Special Rapporteurs and Working Groups, the issuance of reports, the use of questionnaires, dialogue with States and other stakeholders, as well as dialogue with the Sixth Committee. The working methods aim at ensuring that

110 Fuad Zarbiyev, 'Saying Credibly What the Law Is: On Marks of Authority in International Law' (2018) 9 JIDS 291, 297; Richard B Friedman, 'On the Concept of Authority in Political Philosophy' in Joseph Raz (ed), Authority (New York University Press 199o) 68.

111 Michael Barnett and Martha Finnemore, Rules For The World: International Organizations in Global Politics ( $1^{\text {st }}$ edn, Cornell University Press 2004) 20.

112 Zarbiyev (n 110) 294-95; see also Joseph Raz, The Morality of Freedom (Clarendon Press 1986) $35^{-37}$.

113 Hannah Arendt, On Violence (Harcourt, Brace \& World 1970) 45.

114 ILC statute, article 8.

115 ILC statute, article 2.

116 UNGA Res 1103 (XI) (18 December 1956) (increasing the number to 21); UNGA Res 1647 (XVI) (6 November 1961) (increasing the number to 25); UNGA Res 36/39 (18 November 1981) (increasing the number to 34 ). 
the projects are thoroughly researched and carefully worded. ${ }^{117}$ Further, as the only United Nations organ with general competence in the progressive development of international law and its codification, it is the only one capable of addressing a topic in a comprehensive and cross-cutting manner. ${ }^{118}$ Another factor is the involvement of other stakeholders, as foreseen in the statute of the International Law Commission. ${ }^{119}$ Like Matisse's Dance, the Commission is an integral part of a choreography in which various actors play a role. If one of them were to fail, the whole would be weakened. This is particularly true for States. Their participation is essential. Through their comments or lack of comments, as well as their proposals for topics, they can strengthen or weaken the final products of the Commission and, ultimately, the Commission itself. Finally, in addition to this institutional authority, each final product has its own authority, which varies depending on the form chosen, recommendations made to the General Assembly under article 23 of the statute of the International Law Commission, interactions with the Sixth Committee, comments by States, or cooperation with other stakeholders.

The International Law Commission is socially recognized as "the leading body with expertise in international law". ${ }^{120}$ Its final products are often qualified as falling under article 38 , paragraph 1 (d) of the Statute of the International Court of Justice, i.e. "highly qualified publicists". ${ }^{121}$ However, authority is dynamic in nature. It can be gained, it can be lost. It can increase, it can decrease over time. Nothing is set in stone. The Commission and States are the custodians of this authority, in the short-term but also in the longer term.

\footnotetext{
117 John Dugard, 'How effective is the International Law Commission in the development of international law?' (1998) 23 SAfrYIL 34, 38.

118 Yves Daudet, 'Actualités de la codification du droit international' (2003) 303 RdC 110.

119 ILC statute, articles 16, 17, 21, 25 and 26.

120 UNEP (n 108); see also UnGa Res 36/39 (18 November 1981), Recital 1.

121 Caron (n 53) 867; Bertrand G Ramcharan, The International Law Commission: its Approach to The Codification and Progressive Development of International Law (Martinus Nijhoff 1977) 25 .
} 